\title{
Overview of Sprinkler Technology Research
}

\author{
CHENG YAO \\ Factory Mutual Research Corporation \\ Norwood, Massachusetts 02062 USA
}

\begin{abstract}
Sprinkler fire protection has existed for over 100 years. Until recently, however, understanding how a sprinkler protects against fire had not been very important, because sprinklers were so greatly overdesigned for fires in industrial buildings of the past. Since World War II, the traditional sprinkler has been severely challenged to its limit of effectiveness by ever-changing manufacturing and storage practices. In response to this challenge, FMRC initiated a sprinkler technology research program in 1970, to study sprinkler performance principles. This ongoing research identifies and quantifies the controlling variables, such as RTI (Response Time Index), ADD (Actual Delivered Density) and RDD (Required Delivered Density), and develops engineering tools and deterministic computer models to predict sprinkler fire protection performance. Emerging scientific understanding has stimulated new sprinkler developments: the Large-Drop Sprinkler (1971-1980), the Residential Sprinkler (1976-1979), and the ESFR Sprinkler (1984-1986). It is the intention of this paper to present an overview of continuing sprinkler technology research activities, including some practical applications.
\end{abstract}

KEYWORDS: Automatic Sprinkler Systems, Fire Control, Fire Suppression, Sprinkler Performance Characteristics, Sprinkler Technology, ESFR Sprinkler, Large Drop Sprinkler

\section{INTRODUCTION}

The automatic sprinkler was designed originally in the late 1880's to protect against fires in combustible ceiling structures of New England textile mills. The old style sprinkler directed about half of the water upward to protect the ceiling structures; the remainder of the water and that which bounced off the ceiling was distributed toward the fire on the floor. The 13 $\mathrm{mm}$ orifice diameter sprinkler was so overdesigned and the loss experience was generally so favorable, it was essentially unchanged until 1950 when FMRC developed the "Spray" sprinkler in recognition of the important role of water distribution in the protection of storage 
fires. The spray sprinkler directed all the water downward toward the fire on the floor ${ }^{(1)}$. The spray sprinkler was later accepted by the NFPA as the "Standard" sprinkler in 1953, replacing the old style sprinkler.

Since World War II, there have been continuous changes in manufacturing and storage practices, especially the introduction of lift trucks to stock more hazardous synthetic materials in higher buildings, dramatically increasing the challenge to sprinkler protection systems. Under these circumstances, a relatively large number of sprinklers are supplied with sufficient water to control and limit the fire spread within a particular area by keeping the surrounding combustibles wet enough so that they do not ignite. This defensive approach was in practice for many years before it was formally defined as the "Fire Control Concept" in $1984^{(2)}$. Under the control concept, the protection requirement for each storage condition has to be individually determined. FMRC built the world's largest sprinkler fire test facility in 1967 to seek immediate solutions to storage problems through large-scale rack storage and plastic storage fire test programs, which were expensive. In order to provide the data needed with a reasonable number of fire tests, a concept of "Parallelism" was adopted by a committee governing the "Rack Storage Program". This involved the establishment of a base density / area of demand curve for a standard test commodity and a set of test conditions using a specific sprinkler brand. Additional curves for other commodities and variables, such as aisle width, sprinkler temperature rating, and type of rack, were then constructed through a single test point drawn parallel to the base curve. All of the tests were conducted with the ignition source centered below four sprinklers. These guidelines are complex; NFPA 231C, Standard for Rack Storage of Materials ${ }^{(3)}$, has 14 figures and 7 tables. By definition, the density/area rule assumes that for a given water density, the performance of all listed sprinklers in a given category is the same, regardless of their make, orifice size, spacing, or pressure. Unfortunately, over the years, test results have shown that different sprinkler models and ignition locations can cause a significant difference in area demands ${ }^{(4)}$. Furthermore, fire tests in the Plastic Storage Program revealed that rack storage of a plastic commodity over $4.6 \mathrm{~m}$ high cannot be protected without supplementing ceiling sprinklers with in-rack sprinklers. Inrack sprinkler systems, however, are expensive, and a warehouse incorporating them is difficult to operate.

In summary, the traditional sprinkler system has been challenged to its limit of effectiveness, and the area/density rule which has been used as the basis for sprinkler system design is no longer appropriate. In spite of hundreds, if not thousands, of large-scale fire tests under various conditions, very little was known and very few adequate conclusions could be drawn. At the same time, the urgent need for improved fire protection in residential occupancies had raised doubt as to the suitability and effectiveness of an industrial sprinkler in residential and office buildings.

FMRC initiated a long-range sprinkler technology research program in 1970 to study the principles of sprinkler fire protection in an effort to provide a sound technical basis for solving the above mentioned problems. The knowledge which came out of this study has been used to formulate guidelines for developing new and effective fire control and fire suppression sprinkler systems: the Large-Drop sprinkler system (1971-1980) to control high-challenge storage fires, the Residential sprinkler system (1976-1979) to maintain a survivable environment in residential areas, and the Early Suppression Fast-Response (ESFR) sprinkler system (1984-1986) to suppress rather than control high challenge fires. 


\section{SPRINKLER TECHNOLOGY RESEARCH}

In order to establish a scientific and quantitative basis for the understanding of sprinkler fire protection principles, detailed knowledge of the following conditions is needed: 1) fire growth inside the storage array, 2) buoyant fire plume above the storage array, 3) transient ceiling flows, 4) sprinkler response, 5) sprinkler spray and fire plume interaction, and 6) fire suppression criteria.

Fire Challenge at the Time of Sprinkler Operation

Most of the heat detector response prediction models ${ }^{(5,6,7)}$ determine the detector response from cumulative convective heat transfer to the heat sensing element from the ceiling flow. Ceiling flow data have been measured for small-scale steady fires or T-square fire, i.e., fires in which heat release rate increases with time to the second power. All the response prediction models assumed that the heat sensing element is located at an elevation where the ceiling flow temperature and velocity are maximum.

In large-scale rack storage fire tests, the first few sprinklers usually operate while the fire is still confined to the ignition array, represented by an array two-pallet loads wide and twopallet loads deep ( $2 \times 2$ array). A series of free-burn fire tests were conducted with two different classes of commodities: Standard Class II $^{1}$ and Standard Plastic ${ }^{2}$ test commodities, arranged in $2 \times 2$ array at three different heights: two, three and four tiers at 2, 4 and $6 \mathrm{~m}$ high, respectively. These fire tests have been conducted under the FMRC Fire Products Collector (FPC) - a large calorimeter which collects all fire products and determines heat release rates ${ }^{(8)}$. Thermocouples and bi-directional probes were used to measure the fire plume temperature and velocity profiles ${ }^{(9)}$. Some fires were repeated under a large, smooth ceiling to measure the transient ceiling gas temperatures and velocities ${ }^{(10)}$. Empirical correlation of instantaneous gas temperature $\left(\mathrm{T}_{\mathrm{g}}\right)$ and velocity $(\mathrm{U})$ of the ceiling flow at the sprinkler location and the radiative heat gain from the fire plume $\left(\mathrm{Q}_{\mathrm{x}}\right.$. $)$ for both transient and quasi-steady state fire growth characteristics, are used as input data in Equation 1 to predict the response of sprinkler $\left(T_{e}\right)$ at different elevations below the ceiling, for storage fires in large warehouses ${ }^{(11)}$.

$$
\begin{aligned}
& \frac{\mathrm{dT}_{e}}{\mathrm{dt}}=\frac{\mathrm{U}^{1 / 2}\left(\mathrm{~T}_{\mathrm{g}}-\mathrm{T}_{\mathrm{e}}\right)}{\mathrm{RTI}}+\frac{\mathrm{Q}_{\mathrm{r}}}{\mathrm{mc}}-\frac{\mathrm{C}\left(\mathrm{T}_{\mathrm{e}}-\mathrm{T}_{\infty}\right)}{\mathrm{RTI}} \\
& \mathrm{RTI}=\frac{\mathrm{U}^{1 / 2} \mathrm{mc}}{\mathrm{h} \mathrm{A}}
\end{aligned}
$$

where $\mathrm{m}$ is mass of the element, $\mathrm{c}$ is specific heat of the element, $\mathrm{h}$ is the convective heat transfer coefficient, $A$ is surface area of the element, $T_{g}$ is gas temperature, and $T_{\infty}$ is ambient

\footnotetext{
1 Standard Class II Commodity is an FMRC standardized test commodity made of double triwall corrugated cartons with metal liners.

${ }^{2}$ Standard Plastic Commodity is an FMRC standardized test commodity made of polystyrene cups packaged in compartmented cardboard cartons.
} 
temperature. RTI (Response Time Index) represents the thermal responsiveness of the heat sensing element and $\mathrm{C}$ (Conduction Parameter) characterizes the conductive heat loss from the element to the sprinkler support. The values of $\mathrm{RTI}^{(12)}$ and $\mathrm{C}^{(13)}$ are intrinsic properties of a sprinkler design and can be determined experimentally in a test tunnel. Testing of numerous sprinklers shows RTI values ranging from 124 to near $440 \mathrm{~m}^{1 / 2} \mathrm{~s}^{1 / 2}$; for fast response (Residential and ESFR) sprinklers the RTI is $28 \mathrm{~m}^{1 / 2} \mathrm{~s}^{1 / 2}$. The $\mathrm{C}$ value, measured for 11 sprinkler models, ranges from 0.5 to $1.56 \mathrm{~m}^{1 / 2} / \mathrm{s}^{1 / 2}$.

Figure 1 shows the measured and predicted thermal responses of sprinklers at $3 \mathrm{~m} \mathrm{x} 3 \mathrm{~m}$ square spacing and centered directly above a $6 \mathrm{~m}$ high rack storage of standard plastic commodity fire in a $9.1 \mathrm{~m}$ high building. The predicted fast response sprinkler link temperatures at locations both 0.203 and $0.330 \mathrm{~m}$ below the ceiling agree very well with the measured values. Arrows labeled as ESFR are connected to illustrate that the ESFR sprinkler with fast response $\left(\mathrm{RTI}=24.3 \mathrm{~m}^{1 / 2} \mathrm{~s}^{1 / 2}\right)$, low temperature rating $\left(79^{\circ} \mathrm{C}\right)$ link, located at 0.33 $\mathrm{m}$ below the ceiling and $2.1 \mathrm{~m}$ from the fire axis, will respond at $53 \mathrm{~s}$ from ignition with a convective heat release rate of $2.6 \mathrm{MW}$; the Large Drop sprinkler with conventional response $(\mathrm{RTI}=173)$, high temperature rating $\left(142^{\circ} \mathrm{C}\right)$ at $0.203 \mathrm{~m}$ below the ceiling responded at $78 \mathrm{~s}$ with a convective heat release rate of $4.9 \mathrm{MW}$. Not shown here is that if an ESFR sprinkler is centered directly above the same fire, the sprinkler will respond at $50 \mathrm{~s}$ and a convective heat release rate of about 1.5 to $1.8 \mathrm{MW}$.

The principal elements of challenge that a storage fire presents to a sprinkler system is the upward momentum of the fire plume. Figure 2 shows the fire plume temperature and velocity profiles measured at $2.8 \mathrm{~m}$ above a $6 \mathrm{~m}$ high rack storage of standard plastic commodity fire at the convective heat release rates of $1.76 \mathrm{MW}$ and 2.64 MW. Here the center-core momentum flux $\left(\mathrm{M}_{\mathrm{f}}{ }^{\prime \prime}\right)$ values of $21 \mathrm{~N} / \mathrm{m}^{2}$ and $24 \mathrm{~N} / \mathrm{m}^{2}$ were calculated from the local fire plume density $\left(\rho_{\mathrm{f}}\right)$ and velocity $\left(\mathrm{v}_{\mathrm{f}}\right)$ data integrated over a $0.093 \mathrm{~m}^{2}$ circular area around the center-line of the fire plumes.

$M_{\mathrm{f}}^{\prime \prime}=\frac{1}{\mathrm{~A}} \int \rho_{\mathrm{f}} \mathrm{v}_{\mathrm{f}}^{2} \mathrm{dA}$

\section{Sprinkler Performance Characteristics}

At the present time, there are a range of sprinkler sizes available:

\begin{tabular}{|c|c|c|c|c|c|}
\hline \multirow[t]{2}{*}{ Sprinkler Type } & \multicolumn{2}{|c|}{$\begin{array}{l}\text { Nominal Orifice } \\
\text { Diameter }\end{array}$} & \multirow[t]{2}{*}{$\begin{array}{c}\% \text { of } 1 / 2 \text { in. } \\
\text { Sprinkler Flow }\end{array}$} & \multicolumn{2}{|c|}{ K Factor } \\
\hline & $\mathrm{mm}$ & in & & $l / \min /(\text { bar })^{1 / 2}$ & $\mathrm{gpm} /(p s i)^{1 / 2}$ \\
\hline \multicolumn{6}{|l|}{ Spray Sprinkler } \\
\hline Small Orifice & 10 & $3 / 8$ & 50 & 39 & 2.8 \\
\hline Standard Orifice & 13 & $1 / 2$ & 100 & 78 & 5.6 \\
\hline Large Orifice & 14 & $17 / 32$ & 140 & 112 & 7.8 \\
\hline Extra Large Orifice & 16 & 0.64 & 200 & 157 & 11.2 \\
\hline Large-drop Sprinkler & 16 & 0.64 & 200 & 157 & 11.2 \\
\hline ESFR Sprinkler & 18 & 0.7 & 250 & 196 & 14.0 \\
\hline
\end{tabular}




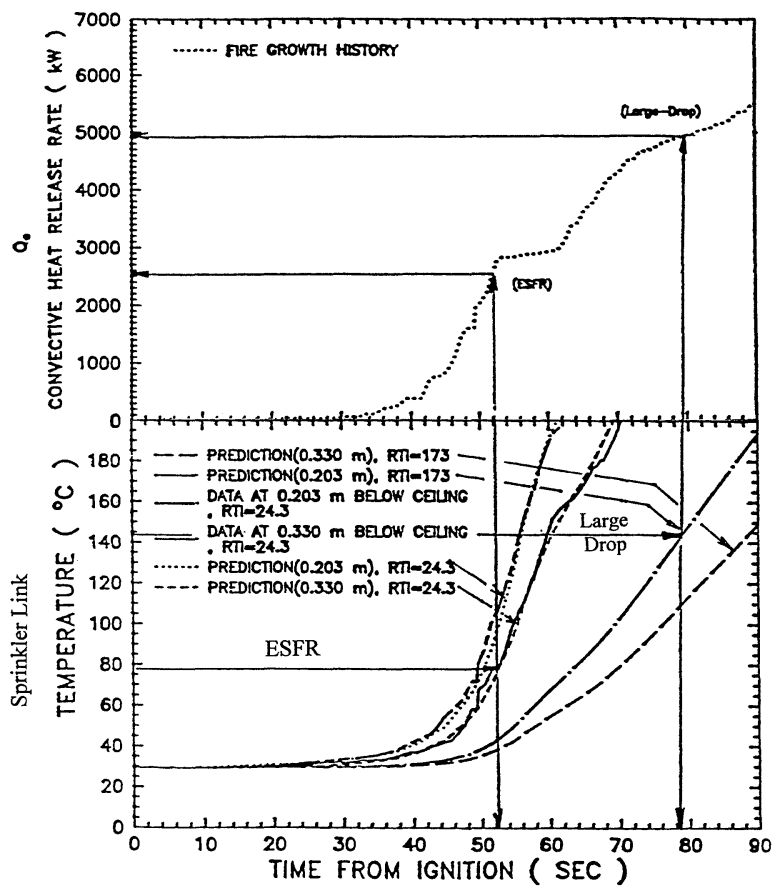

Figure 1. Responses of ESFR Sprinkler (fast response, low temperature link, located $0.33 \mathrm{~m}$ below the ceiling) and Large-Drop Sprinkler (conventional response, high temperature link, located $0.203 \mathrm{~m}$ below the ceiling) for a $6 \mathrm{~m}$ high rack-storage of FMRC Plastic Commodity fire in a $9 \mathrm{~m}$ building, with ignition centered below four sprinklers.

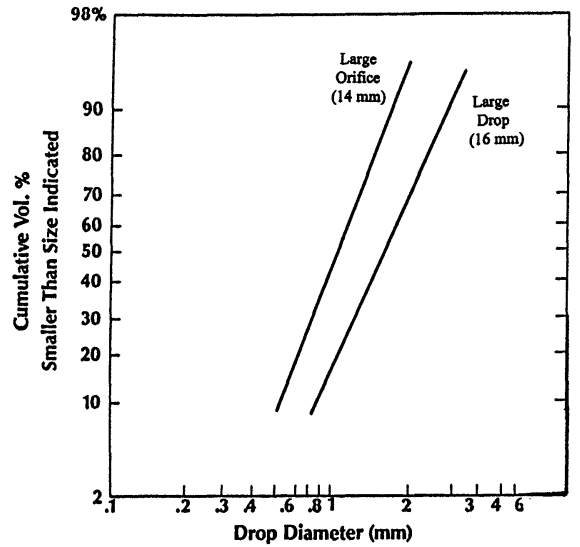

Figure 3. Drop size distribution measured at 2 bar discharge pressure for spray and large-drop sprinklers.

Figure 2. Gaussian plot of fire plume temperature and velocity data measured at $2.8 \mathrm{~m}$ above a $6 \mathrm{~m}$ high rack storage of plastic fire at convective heat release rates of $1.76 \mathrm{~kW}$ and $2.64 \mathrm{~kW}$.

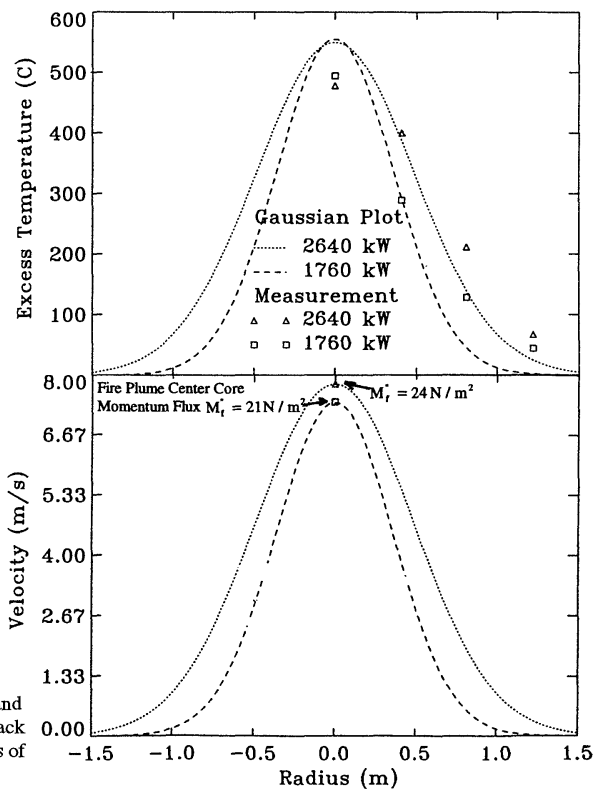


Volumetric sprinkler discharge rate is usually expressed as: $\dot{\mathrm{Q}}_{\mathrm{w}}=\mathrm{K} \mathrm{P}^{1 / 2}$, where $\mathrm{K}$ is flow constant commonly referred to as $\mathrm{K}$ factor, and $\mathrm{P}$ is the water gage pressure. The sprinkler provides a well-defined umbrella-shaped discharge pattern. Water discharge from four sprinklers, when they are spaced $3 \mathrm{~m}$ apart, overlaps at about $1 \mathrm{~m}$ below the deflectors. By definition, design density, $\mathrm{DD}$, is determined from: $\mathrm{DD}=\dot{\mathrm{Q}}_{\mathrm{w}} / \mathrm{A}_{\mathrm{w}}=\dot{\mathrm{Q}}_{\mathrm{w}} / \mathrm{S}^{2}$ where $\mathrm{A}_{\mathrm{w}}$ is designed coverage area per sprinkler and $\mathrm{S}$ is the spacing in square arrangement.

Fire Plume Penetration - ADD: One of the most important measures of sprinkler performance is the ability to deliver water drops through the fire plume to reach the burning surface of the storage array. Under a no-fire condition, water density actually applied (distributed) per unit area within the designed coverage area is the Local Applied Density (LAD); LAD averaged within the designed coverage area is the Local Density (LD). The LD at different elevations below the deflector may be different from the DD. In the presence of a fire, the water density actually penetrating the fire plume and delivered onto the top cross sectional area of the burning array is the Actual Delivered Density (ADD). Therefore, the fire plume penetration performance of a sprinkler can be expressed by a Penetration Ratio $(\mathrm{Pe}=\mathrm{ADD} / \mathrm{LAD})$.

Water drops can penetrate the buoyant fire plume in two modes: the gravity mode and the momentum mode. In the gravity mode, the plume flow is not affected by the downward momentum of the water spray: only large drops in the hot plume having a terminal velocity, $\mathrm{u}_{\mathrm{t}}$, greater than the fire plume velocity will penetrate the fire plume to reach the seat of the fire ${ }^{(14)}$. As shown in Figure 3, the volume median diameter $\left(\mathrm{d}_{\mathrm{m}}\right)$ measured at 2 bar pressure for the Large Drop sprinkler is about $1.5 \mathrm{~mm}$, versus $0.9 \mathrm{~mm}$ for large orifice Spray sprinkler ${ }^{(15)}$. Figure 4 shows the measured terminal velocity ${ }^{(16)}$ as a function of drop diameter in air at various temperatures. For fires in the range of $4.9 \mathrm{MW}$ with about $10 \mathrm{~m} / \mathrm{s}$ plume velocity, drops smaller than $1 \mathrm{~mm}$ will have a great amount of difficulty in penetrating the fire plume by gravity alone. Drops larger than $2 \mathrm{~mm}$ are needed in this situation. However, there is a limit as to how large the drops can be, because drops larger than 3 to $4 \mathrm{~mm}$ in diameter become unstable and break up easily. In the gravity mode, the penetration ratio (Pe) is proportional to drop size $\left(\mathrm{d}_{\mathrm{m}}\right)$. Based on dimensional analysis of pertinent variables, the penetration ratio for sprinklers of similar geometry can be expressed ${ }^{(17)}$ in terms of drop size factor:

$$
\mathrm{Pe} \propto \mathrm{d}_{\mathrm{m}} \propto \frac{\mathrm{D}^{2 / 3}}{\mathrm{P}^{1 / 3}} \propto \frac{\mathrm{D}^{2}}{\dot{\mathrm{Q}}_{\mathrm{w}}{ }^{2 / 3}}
$$

where $\mathrm{D}$ is the orifice diameter of the sprinkler and $\dot{\mathrm{Q}}_{\mathrm{w}}$ is the sprinkler flow rate. In the gravity mode, an increase in orifice diameter will increase the drop size and an increase in pressure will decrease the drop size slightly.

In the momentum mode, the penetration ratio is a function of the Momentum Parameter (M) which is the ratio of the downward momentum of the water spray and the upward momentum of the fire plume. The momentum parameter is important only when it exceeds a critical value, beyond which the sprinkler spray creates a significant effect on the plume, and drop size is no longer important. 
The penetration performance of geometrically similar prototype sprinklers of different scales $^{(17)}$ was measured at different pressures with four sprinklers spaced $3 \mathrm{~m}$ apart and centered at $3.5 \mathrm{~m}$ above a $2.28 \mathrm{MW}$ simulated fire plume generated from the FMRC ADD Apparatus No. $\mathrm{I}^{3}$. Lumping all the values characterizing the simulated fire plumes and water properties into a constant, the momentum parameter for this series of experiments was expressed as:

$$
\mathrm{M}=2.11 \times 10^{-3} \frac{1}{\dot{\mathrm{Q}}_{\mathrm{c}}^{2 / 5}}\left(\frac{\mathrm{K} \mathrm{p}}{\mathrm{S}^{2}}\right)
$$

Figure 5 shows the measured penetration ratio as a function of the drop size factor as defined in Eq. 4. Penetration curves for both scale 1 and scale 1.5 sprinklers turn sharply upward at a point representing the critical condition (drop size factor) for transition from the gravity regime to the momentum regime. For the scale 1 sprinkler, the averaged threshold value on the abscissa is about $0.007 \mathrm{~s}^{2 / 3}$ and occurs at a water pressure of 3.1 bar. From Eq. 5, the associated value which can be considered as a critical momentum parameter $\left(\mathrm{M}_{\mathrm{g}}\right)$ for transition from the gravity to the momentum regime, is determined as: $\mathrm{M}_{\mathrm{g}}=0.204$. This value is found to be the same for all geometrically similar sprinklers.

In order to operate well in the momentum regime, the momentum parameter (M) has to be at least 1.5 times as high as the critical value $\left(\mathrm{M}_{\mathrm{g}}\right)$. From Eq. 5, the critical pressure for the initiation of momentum regime, is influenced strongly by the $\mathrm{K}$ factor, sprinkler spacing, and convective heat release rate. Methods to achieve reduction in the critical pressure to enter more easily into the momentum regime include: 1) use of fast response sprinklers to reduce the convective heat release rate at sprinkler operation, 2) increase in the orifice size, 3) reduction in the spacing, and 4) reduced clearance. Furthermore, the critical value $\mathrm{M}_{\mathrm{g}}$ can vary by a factor of 4 , depending on the sprinkler design and location of the sprinkler in relation to the ignition location.

Large-scale fire test and ADD test results ${ }^{(18)}$ show that ADD is very sensitive to ignition location and ceiling clearance. High clearance is most critical when ignition is located directly under a sprinkler. Low clearance becomes critical when ignition is centered below two or four sprinklers. Typical ADD performance of three different types of sprinklers, operating at 3.4 bar, with one sprinkler located $3 \mathrm{~m}$ directly above the FMRC ADD Apparatus No. $\mathrm{II}^{4}$, are compared in Figure 6. The upright $16 \mathrm{~mm}$ Large Drop sprinkler is operated in the gravity regime: the higher the heat release rate and the lower the ADD value. The pendent $18 \mathrm{~mm}$ ESFR-A sprinkler is clearly operated in the momentum regime, the ADD value does not change significantly with fire size, approaching the unity penetration ratio. For the pendent 16 $\mathrm{mm}$ prototype sprinkler, the ADD value decreases sharply beyond a critical heat release rate.

\footnotetext{
${ }^{3}$ FMRC ADD Apparatus No. I consists of a $1.3 \mathrm{~m}$ diameter water collection pan located below a non-reactive fire plume generated from six commercial premixed gas burners.

${ }^{4}$ FMRC ADD Apparatus No. II consists of four simulated storage commodities. In each of the simulated commodities, there are four water collection systems. The fire plume simulator is a heptane spray fire placed below the bottom of the simulated commodities. Four additional water collection pans are located at the floor level to collect water falling through the FMRC flue spaces between the simulated commodities.
} 


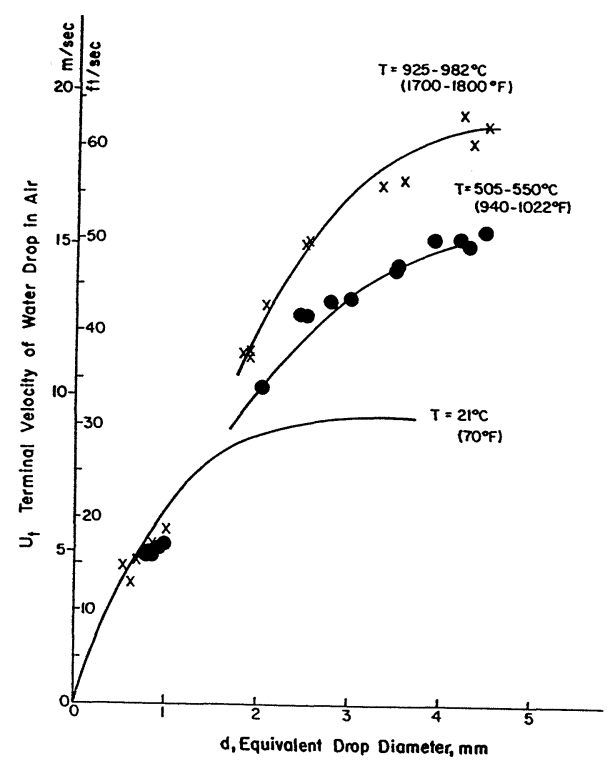

Figure 4. Terminal Velocity of water drops in air at various temperatures.

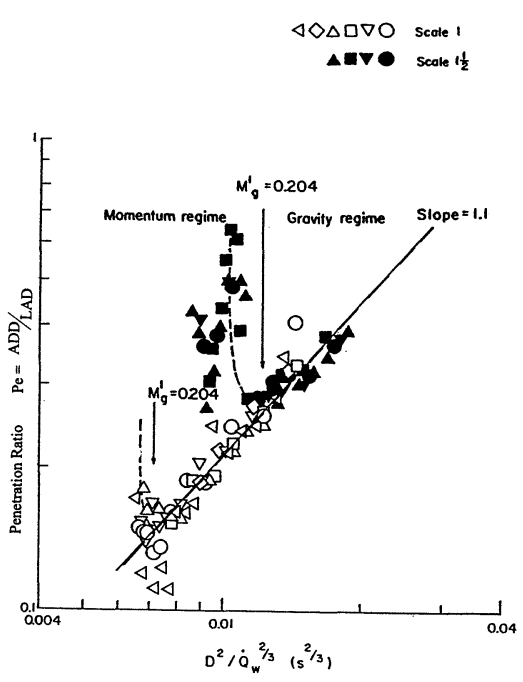

Figure 5. Penetration Ratio for FMRC Geometrically Similar Sprinklers, Scale $1(\mathrm{D}=13 \mathrm{~mm})$ Scale $11 / 2(\mathrm{D}=16 \mathrm{~mm})$.

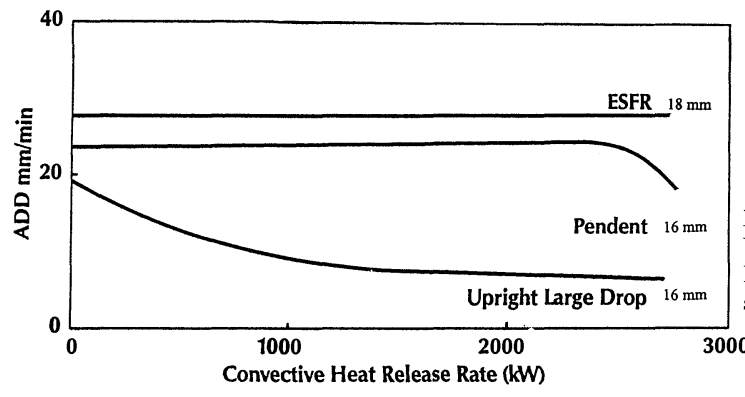

Figure 6. ADD performance of $16 \mathrm{~mm}$ Upright (LDS), $16 \mathrm{~mm}$ pendent and $18 \mathrm{~mm}$ ESFR Sprinklers, operated at 3.4 bar, one sprinkler located $3 \mathrm{~m}$ directly above the fire.

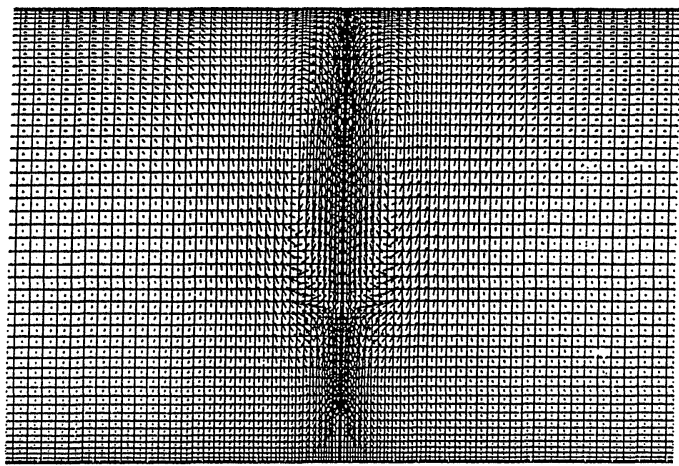

Figure 7. Air flow in the interaction between water spray and the fire: the entrained flow is dominated neither by the plume nor the spray. 
This is a strong demonstration of the effect of critical condition for transition from momentum regime on the left to gravity regime on the right.

The table below shows the sprinkler discharge characteristics of two different models of ESFR sprinklers, ESFR-A and ESFR-B, together with a Large Drop sprinkler and a $13 \mathrm{~mm}$ standard orifice size Spray sprinkler.

\begin{tabular}{|c|c|c|c|c|c|c|}
\hline \multirow[b]{2}{*}{$\begin{array}{c}\text { Sprinkler } \\
\text { Type }\end{array}$} & \multicolumn{3}{|c|}{ Water Pressure 3.4 bar } & \multicolumn{3}{|c|}{ Water Pressure 5.1 bar } \\
\hline & $\begin{array}{l}\mathrm{d}_{\mathrm{m}} \\
(\mathrm{mm})\end{array}$ & $\begin{array}{c}\mathrm{M}_{\mathrm{w}}^{\prime \prime} \\
\left(\mathrm{N} / \mathrm{m}^{2}\right)\end{array}$ & $\begin{array}{c}\mathrm{LAD} \\
(\mathrm{mm} / \mathrm{min})\end{array}$ & $\begin{array}{l}\mathrm{d}_{\mathrm{m}} \\
(\mathrm{mm})\end{array}$ & $\begin{array}{c}M_{\mathrm{w}}^{\prime \prime} \\
\left(\mathrm{N} / \mathrm{m}^{2}\right)\end{array}$ & $\begin{array}{c}\text { LAD } \\
(\mathrm{mm} / \mathrm{min})\end{array}$ \\
\hline ESFR-A & 0.72 & 48.6 & 25.8 & 0.63 & 61.1 & $36^{*}$ \\
\hline ESFR-B & 0.67 & 97.1 & 33.3 & 0.59 & 145.7 & $42 *$ \\
\hline LDS & 1.43 & & 16 & & & \\
\hline Standard & 0.73 & $<4.3$ & 5 & & & \\
\hline
\end{tabular}

The center-core momentum flux of the spray, $M_{w}^{\prime \prime}$, was determined experimentally from the total thrust force impinging on a $0.093 \mathrm{~m}^{2}$ circular load cell disk which was centered directly under a sprinkler, at $2.13 \mathrm{~m}$ below the ceiling. The LAD is water density averaged over an area of $5.23 \mathrm{~m}^{2}$, simulating the top cross-sectional area of a $2 \times 2$ storage array at $3 \mathrm{~m}$ below the ceiling; those marked with * were measured at $4.42 \mathrm{~m}$ below.

The ESFR-A sprinkler, measured with higher ADD value, near $100 \%$ penetration, in Figure 6 , has a smaller drop size, $\mathrm{d}_{\mathrm{m}}$, than the Large-Drop sprinkler. Comparison of the center-core momentum flux of sprinkler spray with that for fire plume (Figure 2), at the time of ESFR sprinkler operation: $\mathrm{M}_{\mathrm{w}}^{\prime \prime} / \mathrm{M}_{\mathrm{f}}^{\prime \prime}=48.6 / 21=2.3$, shows that the center-core momentum flux of the sprinkler has to be at least twice as large as the fire plume in order to approach $100 \%$ penetration. Although both ESFR-A and ESFR-B were approved for protection of $9.1 \mathrm{~m}$ high warehouses, ESFR-B, with smaller drop size and higher center-core momentum flux than ESFR-A, was proven to be more effective in suppressing plastic fires in a $12.2 \mathrm{~m}$ high building ${ }^{(19)}$.

Computer Modeling of Sprinkler Spray and Fire Plume Interaction: Numerical simulation of the interaction between a sprinkler spray and a fire plume was first attempted by Alpert ${ }^{(20)}$. A SPRAY Code was developed to simulate two-dimensional Cartesian or Axisymmetric flows induced by sprinkler spray and fire. In comparing the predicted ADD value using the SPRAY Code with the measured ADD value, $\mathrm{Bill}^{(21)}$ found that while the model successfully captures the trend of the experimental results, it has a few drawbacks and becomes unstable in many instances.

In a recent attempt with a significantly modified PHOENICS code, $\mathrm{Nam}^{(22)}$ simulated the interaction by combining two separate numerical models: a sprinkler spray without fire and a fire plume without spray. Using the measured drop size, density distribution and thrust force distribution as input data, and an accurately modeled free burn fire plume to predict ADD values of ESFR-A and ESFR-B sprinklers, the numerically predicted ADD values are in good agreement with the measurements at low water flow rate (low pressure). The predicted values become much lower than the measurements at high water pressure when the sprinkler momentum has significant impact on the fire momentum. The calculated ADD values from low to high sprinkler discharge rates had to be adjusted to match the measurements by gradual reduction of the heat release rate from $100 \%$ to $40 \%$ of the free-burn-fire sizes. The 
experiments were performed with the FMRC ADD Apparatus No. $\mathrm{III}^{5}$, in which the heptane spray is completely exposed to sprinkler water spray. It is possible that the actual sizes of the spray fire, at high water flow rates, were reduced, due to the water drops washing away the liquid heptane spray droplets before they were vaporized. The ADD value, as defined, should not include the effects of suppression or extinction of a heptane spray fire plume, because the pyrolysis and most of the combustion process were completed within the storage fuel array.

Figure 7 shows the numerically simulated air flow movement in the transition from the gravity mode to the momentum mode of penetration, where the entrained flow is dominated neither by the fire plume nor the spray.

\section{Fire Suppression Criteria}

Protection requirements are usually stated in the standards and codes as density/area of demand or total water volume needed over a time period. Actually only a few sprinklers discharge water toward the burning area, and a fraction of these can actually deliver water to the burning surfaces for fire suppression. In a typical three-dimensional rack storage fire, at the time of the first few sprinkler responses, the fire is still spreading vertically from the burning commodities stored in the bottom two or three tiers. Flames appearing over the storage array result from the burning of the pyrolyzed volatiles. The customary view is that cooling of the flame near the ceiling by the spray droplets will have an insignificant effect on the fire spread in the portion of the storage array which is shielded from the spray discharge. Under these circumstances, the primary mode of sprinkler fire suppression is the cooling of the burning and pyrolyzing surfaces by the flowing and trickling water delivered onto the top surfaces of the stored array. In fact, there is a limit as to how far the trickling water can reach the burning products if they are deep-seated inside the cardboard cartons. In the clean up stage of a large-scale fire test, even hose streams are not expected to extinguish the residue fires without the help of physical removal of burning commodities from the storage racks. This is the reason that we emphasize fire suppression instead of fire extinguishment or extinction in sprinkler technology research.

Fire suppression tests were conducted under the FMRC Fire Products Collector using various standardized test commodities in a realistic rack storage arrangement to gain insight on fire suppression. There are also two categories of standardized tests to classify or evaluate the fire hazards of real world storage commodities: 1) commodity evaluation for fire control and 2) Required Delivered Density (RDD) tests for fire suppression. In these tests, water is applied uniformly on top of the storage array when the fire grows to a pre-selected size.

Critical Water Application Density for Fire Suppression: The status of fire extinction research with water up to 1986 has been reviewed by Heskestad ${ }^{(23)}$ and Rasbash ${ }^{(24)}$. Most of these fire extinction data were converted to a critical water application density, $\dot{\mathrm{m}}_{\mathrm{cr}}$ ", grams of water per second per unit of entire surface area $\left(\mathrm{g} / \mathrm{s} \mathrm{m}^{2}\right)$, below which the fuel will be completely consumed; above the critical density, the time to extinguishment decreased rapidly.

\footnotetext{
${ }^{5}$ ADD Apparatus No. III consists of twenty water collection pans which are assembled to simulate the top surface of a $2 \times 2$ rack storage array, including the flue spaces between the simulated commodities. The fire plume simulator is a heptane spray fire placed on top of the water collection system.
} 
For wood slabs, cribs and pallet fires with $5-60 \%$ preburn, $\dot{\mathrm{m}}_{\mathrm{cr}}$ " values vary from 1.5 to $3 \mathrm{~g} / \mathrm{s}$ $\mathrm{m}^{2}$, and those for wood cribs and pallet fires are higher than wood slabs. For a fire initiated at one end of a wood crib, water application density necessary to limit lateral fire spread to the entire crib (for fire control) were considerably smaller $\left(0.7-1.1 \mathrm{~g} / \mathrm{s} \mathrm{m}^{2}\right) . \dot{\mathrm{m}}_{\mathrm{cr}}{ }^{\prime \prime}$ values for plastic slabs range from $1.2 \mathrm{~g} / \mathrm{s} \mathrm{m}^{2}$ for horizontal PMMA to $4.4 \mathrm{~g} / \mathrm{s} \mathrm{m}^{2}$ for Polyethylene. $\mathrm{m}_{\mathrm{cr}}{ }^{\prime \prime}$ values were considerably higher with external radiation.

About one hundred forty fire suppression tests on FMRC standardized Class II and Plastic test commodities were conducted using $2 \times 2$ rack storage arrays ranging from two to five tiers high $^{(25)}$. A fire suppression model ${ }^{(2)}$ was developed to analyze the test results. This model employs a global energy balance between the heat flux received by the fuel surfaces from the flame and the heat absorbed by water due to evaporation to determine the total rate of pyrolysis of the commodities stored in the test rack, during a time period after water application. Based on this model, a fire suppression parameter, $\mathrm{k}$, was identified to correlate the fire suppression results, expressed as a ratio of $\Delta \mathrm{Q}_{\mathrm{a}} / \Delta \mathrm{Q}_{\mathrm{ao}}, \Delta \mathrm{Q}_{\mathrm{a}}$ is the cumulative total heat release in a time period starting from water application $\mathrm{t}_{0} . \Delta \mathrm{Q}_{\mathrm{ao}}$ is a reference cumulative heat release in a time period assuming the fire stopped growing at the start of the water application.

$$
\begin{aligned}
& \frac{\Delta \mathrm{Q}_{\mathrm{a}}}{\Delta \mathrm{Q}_{\mathrm{ao}}}=\frac{1-\exp \left[-\mathrm{k}\left(\mathrm{t}-\mathrm{t}_{0}\right)\right]}{\mathrm{k}\left(\mathrm{t}-\mathrm{t}_{0}\right)} \\
& \mathrm{k}=\frac{\alpha\left(\dot{\mathrm{m}}_{\mathrm{w}}^{\prime \prime} \mathrm{Q}_{\mathrm{w}}-\beta \dot{\mathrm{m}}_{\mathrm{f}}^{\prime \prime} \Delta \mathrm{H}_{\mathrm{c}}+\dot{\mathrm{m}}_{\mathrm{f}}^{\prime \prime} \mathrm{Q}_{\mathrm{p}}\right)}{\rho_{\mathrm{f}} \mathrm{c}\left(\mathrm{T}_{\mathrm{p}}-\mathrm{T}_{\infty}\right)}
\end{aligned}
$$

where $Q_{w}$ is the heat of evaporation of water. $T_{p}$ is average temperature of the layer of fuel undergoing pyrolysis and $\mathrm{T}_{\infty}$ is the ambient temperature. The fire suppression parameter $\mathrm{k}$, which increases linearly with water application density $\left(\dot{\mathrm{m}}_{\mathrm{w}}{ }^{\prime \prime}\right)$, is a function of fuel flammability, expressed in parameters such as density $\left(\rho_{\mathrm{f}}\right)$, specific heat $(\mathrm{c})$, heat of combustion $\left(\Delta \mathrm{H}_{\mathrm{c}}\right)$, burning rate per unit burning surface area $\left(\dot{\mathrm{m}}_{\mathrm{f}}{ }^{\prime \prime}\right)$, heat of pyrolysis $\left(\mathrm{Q}_{\mathrm{p}}\right)$, fraction of total heat release rate (flame heat flux) transferred to the fuel surface $(\beta)$ and fuel geometric factor $(\alpha)$.

Figure 8 represents the ratio, $\Delta \mathrm{Q}_{\mathrm{a}} / \Delta \mathrm{Q}_{\mathrm{ao}}$, versus $\mathrm{k}$ for both the class II and the plastic commodities stored in racks of different heights. The ratio, $\Delta \mathrm{Q}_{\mathrm{a}} / \Delta \mathrm{Q}_{\mathrm{ao}}$, measured during a period after the water application of $\mathrm{t}-\mathrm{t}_{0}=240 \mathrm{~s}$, correlated well with the fire suppression parameter, $\mathrm{k}$, as defined in Eq. 7. By setting $\Delta \mathrm{Q}_{\mathrm{a}} / \Delta \mathrm{Q}_{\mathrm{ao}}=1$ in Eq. 6, the critical water density per unit exposed surface area for water application (the entire surface area minus the bottom area of the commodity) for the Standard Class II commodity was determined as $6 \mathrm{~g} / \mathrm{s}$ $\mathrm{m}^{2}$; and that for plastic commodity was found to be in the range of $17 \mathrm{~g} / \mathrm{s} \mathrm{m}^{2}$ to $20 \mathrm{~g} / \mathrm{s} \mathrm{m}^{2}$. The critical water density for Standard Class II commodity can be converted into $\dot{\mathrm{m}}_{\mathrm{cr}}{ }^{\prime \prime}=5 \mathrm{~g} / \mathrm{s}$ per unit of entire surface area, in comparison to 1.5 to $3 \mathrm{~g} / \mathrm{s} \mathrm{m}^{2}$ for wood slabs, cribs, and pallets. It appears that combustible type, geometry, packaging and storage arrangement have significant impact on the magnitude of the critical water density. These factors, especially 


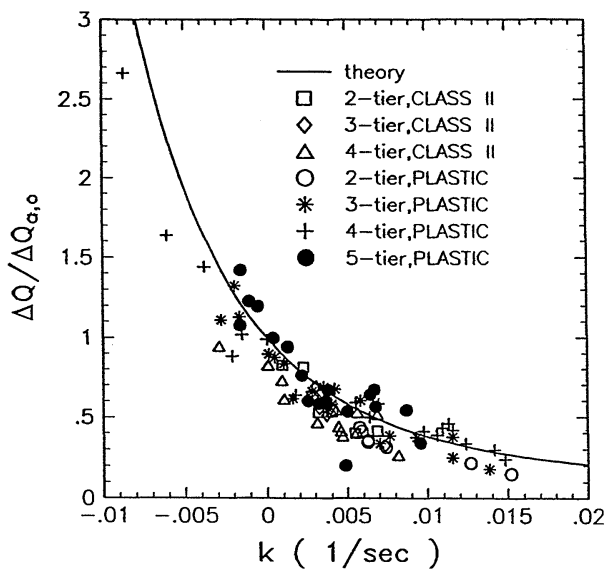

Figure 8. The correlation of fire suppression test results with the fire suppression parameter, $\mathbf{k}$.
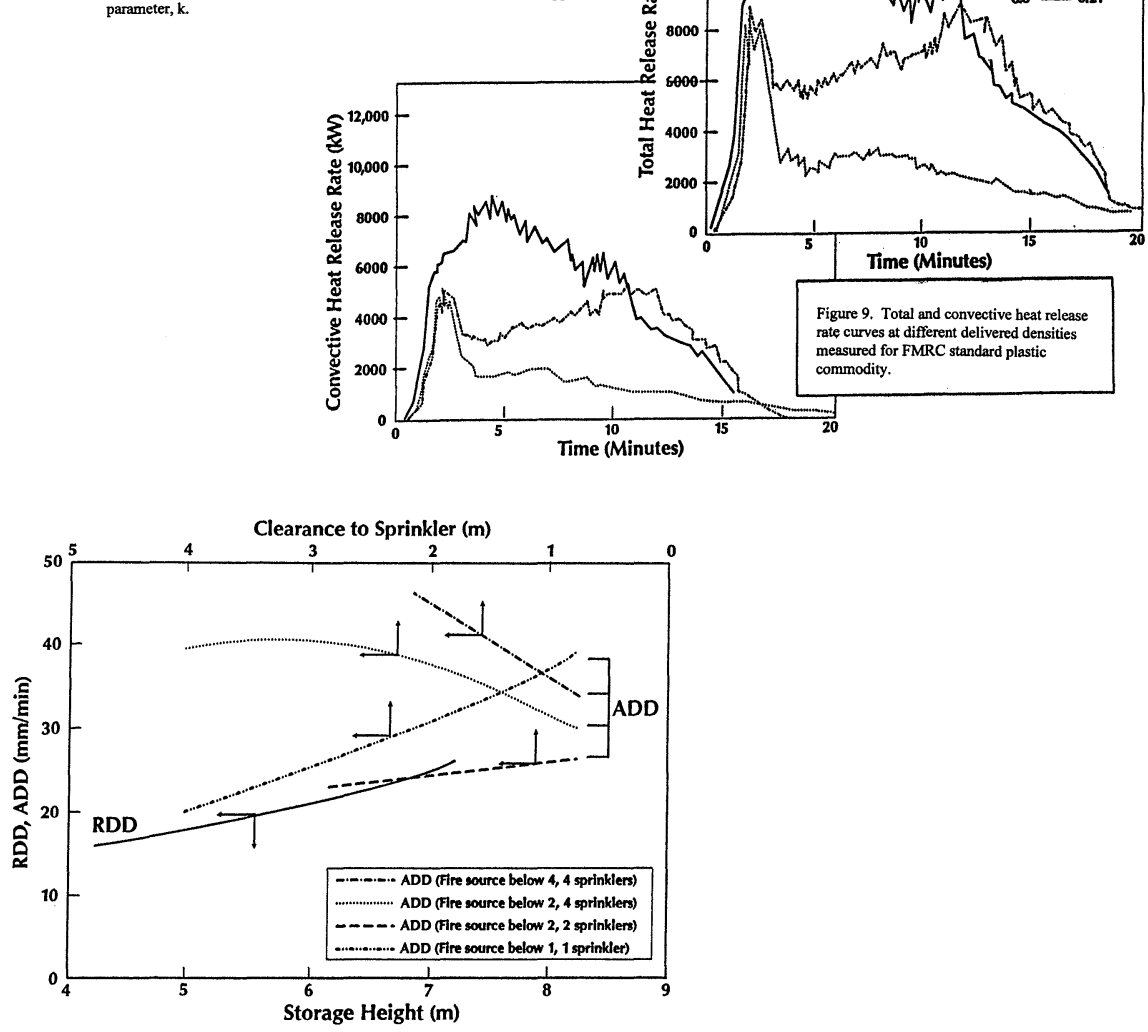

Figure 10. A cross plot of measured ADD and RDD values as a function of storage height, clearance in a $9 \mathrm{~m}$ building for different ignition locations. 
with their influence on the flame heat flux to the exposed fuel surfaces or the $\beta$ value inside the storage array, have to be clarified and quantified before the fire suppression results of small-scale tests can be used to assess the fire suppression results of the corresponding largescale tests.

There have been numerous studies of flame heat fluxes on the single and parallel burning walls. In the last two years, Ingason ${ }^{(27)}$ has provided measurements of the heat flux distribution at the surface of an idealized fire spread in the $2 \times 2$ storage array, i.e., four equally separated rectangular towers, exposed to flames from a circular gas burner at the floor. It was found that the flame height data and excess gas temperature data within the storage array, appear to follow axisymmetric fire plume laws. Comparison of the flame height data with that measured from large scale rack storage of Standard Class II commodity tests shows good agreement. Formulas for the flame heat flux distribution in terms of the total fire heat release rate, fuel sootiness and separation distance are provided. It is expected these data can be used to predict fire growth in storage geometries and employed in the fire suppression model as defined in Eqs. 6 and 7 above.

Commodity Evaluation for Fire Control: Sprinkler protection requirements of storage occupancies for fire control systems were developed from large-scale fire tests using different standardized test commodities. A less costly intermediate-scale fire test protocol was developed to classify fire protection (control) challenges of different storage commodities ${ }^{(28)}$. The test apparatus consists of a special water applicator that is capable of spreading a fairly uniform distribution of water directly over the top surface of the burning fuel array, thus simulating water that has penetrated the fire plume (ADD). This apparatus is positioned below the FMRC Fire Products Collector. The water applicator is actuated at a specific heat release rate (as measured by the FPC), which corresponds to that of a sprinkler actuating in a building with $3 \mathrm{~m}$ clearance.

This test procedure is to classify the hazard of a commodity stored on a $2 \times 2 \times 2$ tiers high rack segment based on the delivered density that merely controls the fire. With this method, the potential fire protection challenge of an unknown storage or test commodity can be measured in terms of heat release rates (total, convective and radiative) under different water application rates. Heat release rate curves, measured for an unknown storage commodity, are then compared with those measured for the standard test commodities, especially under the water application densities where the fires are not suppressed (Figure 9). This quantitative test method is being used to classify an unknown storage commodity into proper fire protection category.

Required Delivered Density (RDD) for Fire Suppression: Different from the commodity evaluation test protocol for fire control, the RDD test protocol was developed to determine the water density which must be delivered to the top of a burning storage array in order to achieve a pre-determined degree of fire suppression. The test procedure is similar to the commodity evaluation tests except that RDD values are determined for different storage heights in a $9.1 \mathrm{~m}$ high building, accepting only the results obtained from a successfully suppressed test based on a criterion of no more than $10 \%$ fuel consumption of the test array during the entire fire suppression period. 
For the ESFR sprinkler located $0.33 \mathrm{~m}$ below a $9.1 \mathrm{~m}$ high ceiling, the fire sizes at sprinkler actuation for fires of different storage heights are all within the range of 1.5 and $2.64 \mathrm{MW}$ convective heat release rates. The measured RDD values for a given storage height do not change significantly within this range of heat release rates. Consequently, a single RDD value measured at 2.64 MW was selected for each of the three-, four- and five-tier high rackstorage of plastic commodity in a $9.1 \mathrm{~m}$ high building as $16.3,20.4$ and $26.5 \mathrm{~mm} / \mathrm{min}^{(18)}$. It was found recently ${ }^{(27)}$ that the above $\mathrm{RDD}$ values corresponded to a $\Delta \mathrm{Q}_{\mathrm{a}} / \Delta \mathrm{Q}_{\mathrm{a}}$ ratio of 0.67 in Figure 8. Based on this ratio, the fire suppression parameter, $\mathrm{k}$, is determined to be 0.00357 . Using the same ratio, the RDD values for Standard Class II commodity were about $6.9,10.5$ and $13.4 \mathrm{~mm} / \mathrm{min}$ for 2-, 3- and 4- tier fuel arrays.

\section{APPLICATION OF SPRINKLER TECHNOLOGY}

Knowledge gained from sprinkler technology research has been used to develop the following three new performance oriented sprinklers: 1) Large Drop sprinkler - designed to provide better fire control by producing a higher proportion of large drops to penetrate the fire plume, 2) Residential sprinkler - customized to maintain a survivable environment in residential areas, and 3) ESFR sprinkler - optimized to overpower the fire plume and deliver enough water at the early stage of development to suppress the fire before it becomes a severe challenge.

\section{Development of Large Drop Sprinkler (LDS) System}

The Large-Drop sprinkler was developed during the period from 1970 to 1980 . It was designed to provide: 1) higher water discharge using a maximum orifice size of $16 \mathrm{~mm}$ (0.64 in), the highest water discharge possible in a retrofit to a $1 / 2$ in pipe thread; and 2) significantly large drops in comparison to large orifice Spray sprinkler (Figure 3). Against a 45 liter/min heptane spray fire plume, four Large Drop sprinklers centered above the fire, deliver three times as much water to the seat of the fire as four large orifice Spray sprinklers under the same discharge pressure ${ }^{(29)}$.

Results are tabulated below from a series of four large-scale fire tests, using Large Drop sprinklers installed at different sets of spacing and operating pressure combinations to provide the same designed density (DD) of $24.4 \mathrm{~mm} / \mathrm{min}$, to protect a $6 \mathrm{~m}$ high palletized storage of plastic commodity in a $9.1 \mathrm{~m}$ high building which could not be protected with Spray sprinklers, at the ceiling only, under any operating conditions :

\begin{tabular}{lcccc} 
Sprinkler Type & LDS & LDS & LDS & LDS \\
Orifice Size, in & 0.64 & 0.64 & 0.64 & 0.64 \\
\multicolumn{1}{c}{ mm } & 16 & 16 & 16 & 16 \\
Density, mm/min & 24.4 & 24.4 & 24.4 & 24.4 \\
Spacing, ${ }^{2}$ & 12 & 9.3 & 7.4 & 3.1 \\
Pressure, bar & 3.3 & 1.9 & 1.2 & 0.5 \\
No. Open & 10 & 18 & 33 & 152 \\
Total Flow, liter/min & 2530 & 3710 & 5150 & 13600 \\
Area of Demand, $\mathrm{m}^{2}$ & 120 & 167 & 244 & 465
\end{tabular}


This comparison shows that at the same density, the area of water demand increased from 120 to $465 \mathrm{~m}^{2}$ as the spacing and pressure were decreased from $12 \mathrm{~m}^{2}$ at 3.3 bar to $3.1 \mathrm{~m}^{2}$ at 0.5 bar. It is clear that the area-density rule is not valid. Therefore, the Large-Drop sprinkler standards are presented in terms of number of sprinklers at the minimum specified pressure (no less than 1.7 bar) for the occupancy. The spacing of Large Drop sprinklers is limited to a minimum of $7.4 \mathrm{~m}^{2}$ and a maximum of $9.3 \mathrm{~m}^{2}$. Against the $6 \mathrm{~m}$ high palletized storage of plastics, Large Drop sprinkler operation at 1.9 bar resulted in a $50 \%$ reduction in water demand in comparison with the standard sprinklers as shown in the last column on the right. Furthermore, the Large Drop sprinkler, operating at 3.3 bar and $9.3 \mathrm{~m}^{2}$ spacing, has extended the upper boundary of sprinkler effectiveness to $6 \mathrm{~m}$ high rack storage of plastic commodity in a $9.1 \mathrm{~m}$ building. Currently, there are two FMRC Approved large drop sprinklers on the market.

\section{Development of the Residential Sprinkler System}

From 1976 to 1982, research results demonstrated the need for fast-response (low RTI) sprinklers with different discharge patterns for providing adequate life-safety protection in residential fires. Based on the information gained ${ }^{(30,31)}$, fast-response (low RTI) Residential sprinklers have been developed by the U. S. Sprinkler Industry. Since 1983, work in this area has been expanded to include: 1) fast-response sidewall sprinklers for residential and hotel applications, 2) effects of cathedral and beamed ceiling construction on residential sprinkler performance, and 3) application of fast-response sprinklers in office occupancies.

Residential sprinklers were developed before it was fully established that ADD and RDD are key factors in determining early fire suppression performance. Suppression capabilities of Residential sprinklers and fast (quick)-response Spray sprinklers under a residential fire scenario have been investigated using the procedures outlined for the ESFR development program in a series of seven full-scale fire tests ${ }^{(32,33)}$. Suppression or no-suppression predictions based on ADD/RDD relationships were verified in five tests. Suppression occurred in two tests even with $\mathrm{ADD}<\mathrm{RDD}$. The ADD/RDD approach provided a conservative means for predicting fire suppression in this test program.

\section{Development of ESFR Sprinkler System}

ESFR stands for Early Suppression Fast Response. ES was placed intentionally before FR to emphasize the end rather than the means. The ESFR sprinkler system was developed originally to provide early suppression performance on high challenge storage fires represented by up to $7.6 \mathrm{~m}$ high rack storage of standard plastic commodity in a $9.1 \mathrm{~m}$ high building. The basic ESFR concept is that if a required quantity of water can be delivered to a fire in the early stages of its development, suppression will be quickly achieved; thus, fewer sprinklers will operate, and less fire and water damage will result ${ }^{(2)}$.

In principle, early suppression performance is determined by three factors ${ }^{(2,18)}$, which can be independently measured: 1) Response Time Index (RTI), 2) Actual Delivered Density (ADD), and 3) Required Delivered Density (RDD). The RTI and the time-dependent nature of ADD and RDD determine the early suppression performance of the ESFR sprinkler system. 
The premise of the ESFR system is to ensure ADD in excess of RDD, regardless of ignition location.

As shown in Figure 5, the most effective way of delivering a large quantity of water to the base of the fire plume, is to ensure that the sprinklers are always operating in the far left of the momentum regime. Based on Eq. 5, two methods can be used to achieve this at a fast response heat sensing element, and 2 ) increasing the $\mathrm{K}$ factor of the sprinkler. In addition, the critical value for transition, $\mathbf{M}_{\mathbf{q}}$, can also be reduced significantly through an innovative sprinkler design to provide a sprinkler spray with strong momentum to overpower the upward momentum of the fire plume. This is the guiding principle behind the ESFR Sprinkler development.

Figure 10 is a cross-plot of measured ADD and RDD values as a function of storage height and clearance in a $9.1 \mathrm{~m}$ high building for different ignition locations. It shows that for only one sprinkler centered over the fire source, high clearance (low storage height) is critical; with two and four sprinklers, low clearance (high storage) is critical. There were three years of intensive ADD testing to develop the first ESFR prototype and a series of large-scale doubleand multiple-row rack storage fire tests, during the period of 1985 - 1986. Results of these fire tests ${ }^{(18)}$ not only confirm that the prototype ESFR sprinkler would perform well in the critical conditions, they also demonstrate that even under the worst failure mode condition tested, ignition between two sprinklers with one of them plugged, the fire was still controlled with 11 sprinklers.

ESFR sprinklers have been shown to be effective for most common materials up to and including unexpanded plastics, in cardboard cartons or exposed, in single-row, double-row and multiple-row rack storage or in solid-piled, palletized or open-frame storage up to $10.6 \mathrm{~m}$ high in a $12.2 \mathrm{~m}$ high warehouse. The list of commodities protectable by ESFR sprinklers has been extended to include expanded plastic, nonwoven and aerosol products. Also, lesser hazard commodities, lower storage heights, or ceiling heights lower than 9.1 and $12.2 \mathrm{~m}$ are protected with the same water demand: 12 sprinklers at a minimum water pressure of $3.4 \mathrm{bar}$ and 5.1 bar for 9.1 to $12.2 \mathrm{~m}$ high warehouses, respectively.

Currently there are four FMRC Approved ESFR sprinklers on the market. They are of pendent design with an orifice diameter of $18 \mathrm{~mm}(0.7 \mathrm{in}$.). The sprinkler link used is rated $74^{\circ} \mathrm{C}$ with a RTI of $22-36 \mathrm{~m}^{1 / 2} \mathrm{~s}^{1 / 2}$.

\section{FUTURE TECHNOLOGICAL TRENDS}

The successful applications of sprinkler technology in residential and high challenge warehouse (up to $12.2 \mathrm{~m}$ high) fire protection represent only two segments of an entire spectrum of fire challenge. There is a need to expand the application: to develop ESFR sprinklers of smaller orifice sizes for medium challenge occupancies, such as manufacturing and assembling plants, public and institutional buildings as well as ESFR sprinklers of larger than $18 \mathrm{~mm}$ orifice size. Undoubtedly, a more tolerable design method than the initial ESFR program with its "one size fits all" approach is needed. Design methodology of the next generation of ESFR sprinklers will require technically sound predictive models. These models 
will be used to predict whether a sprinkler spray can deliver the RDD for the suppression of a particular fire situation. The future performance-oriented sprinkler standard will be backed up with a computer simulation design guide. One ultimate goal is to develop a phenomenological sprinkler performance model intended to simulate a high-challenge sprinklered warehouse fire. The model will be expanded to provide a systematic method for the mitigation of the consequences such as fire damage and nonthermal damage, as well as potential damage from water run-offs.

\section{REFERENCES}

1. Thompson, N. J., "Fire Behavior and Sprinklers," National Fire Protection Association, Quincy, MA, 1964.

2. Yao, C., Marsh, W. S., "Early Suppression - Fast Response: A Revolution in Sprinkler Technology," Fire Journal, National Fire Protection Association, Quincy, MA, Jan. 1984, pp. 44-46.

3. NFPA 231 C: Standard for Rack Storage of Materials," National Fire Protection Association, Quincy, MA USA, 1991 Edition.

4. Vincent, G. B. and Kung, H-C., "Comparison of European Conventional and U.S. Spray Sprinklers," J. of Fire Protection Engineering, 5 (1) 1993, pp. 17-28.

5. Alpert, R.L., "Calculation of Response Time of Ceiling Mounted Fire Detectors," Fire Technology, Vol. 8, No.3, August 1972.

6. Evans, D.D., and Stroup, D.W., "Methods to Calculate the Response of Heat and Smoke Detectors Installed Below Large Unobstructed Ceilings," Fire Technology, Vol. 22, No. 1, 1985, pp. 54-65.

7. Heskestad, G., and Delichatsios, M.A., "The Initial Convective Flow in Fire," The Seventeenth Symposium (International ) on Combustion, 1978, pp. 1113-1123.

8. Yu, H-Z, "Transient Plume Influence in Measurement of Convective Heat Release Rates of Fast-Growing Fires Using a Large-Scale Fire Products Collector", Journal of Heat Transfer, Vol. 112, 1990, pp. 186-191.

9. You, H. Z. and Kung, H. C., "Strong Buoyant Plumes of Growing Rack Storage Fires," Twentieth Symposium on Combustion, The Combustion Institute, 1984.

10. Yu, H-Z., and Stavrianidis, P., "Transient Ceiling Flows of Growing Rack Storage Fires," Proceeding of the Third International Symposium on Fire Safety Science, International Association for Fire Safety Science, pp. 281-290, 1991.

11 Yu, H-Z., "Sprinkler Response Prediction for Warehouse Rack Storage Fires," Publication in preparation, 1996.

12. Heskestad, G. and Smith, H. F., "Investigation of a New Sprinkler Sensitivity Approval Test: The Plunge Test," FMRC 22485, Factory Mutual Research Corporation, Norwood, Massachusetts, December 1976.

13. Heskestad, G. and Bill, R. G., "Quantification of Thermal Responsiveness of Automatic Sprinklers - Including Conduction Effects", Fire Safety J., 14, 1988, pp. 113-125.

14. Yao, C. and Kalelkar, A. S., "Effect of Drop Size on Sprinkler Performance," Fire Technology, Vol. 6, No. 4, November 1970, pp. 254-268.

15. Yu, H-Z., "Investigation of Spray Pattern of Selected Sprinkler with the FMRC Drop Size Measuring System," Proceeding of the First International Symposium on Fire Safety Science, pp. 1165-1176, Hemisphere, 1986. 
16. Yao, C., "Development of Large Drop Sprinklers" FMRC Technical Report No. 22476, Factory Mutual Research Corporation, Norwood Mass., June 1976.

17. Heskestad, G., "Sprinkler Performance as Related to Size and Design, Vol. 1Laboratory Investigation,' FMRC Technical Report No. 22437, 1979.

18. Yao, C., "The Development of the ESFR Sprinkler System", Fire Safety Journal, 14 (1988) pp. 65-73.

19. Kung, H-C., Vincent, B., Chan, T-K., Yu, H-Z., and Stavrianidis, S., "Early Suppression Fast Response (ESFR) Sprinkler Protection for $12 \mathrm{~m}$ High Warehouses" to be published in the Proceeding of the Fifth International; Symposium on Fire Safety Science, 1996.

20. Alpert, R. L., "Numerical Modeling of the Interaction Between Automatic Sprinkler Sprays and Fire Plumes," Fire Safety J., 9, 1985, pp.157-163.

21. Bill, R. G., Jr. "Numerical Simulation of Actual Delivered Density Measurements," fire Safety J., 20, 1993, pp. 227-240.

22. Nam, S., "Development of a Computational Model Simulating the Interaction Between a Fire Plume and a Sprinkler Spray," Fire Safety Journal, 26, 1996.

23. Heskestad, G., "The Role of Water in Suppression of Fire: A Review", Journal of Fire \& Flammability, Vol. 11 (October 1980) p.254.

24. Rasbash, D. J., "The Extinction of Fire with Plain Water," The Proceedings of the First International Symposium of Fire Safety Science, Hemisphere Publishing Corporation, pp. 1145-1163, 1986.

25. Lee, J. L., "Extinguishment of Rack Storage Fires of Corrugated Cartons Using Water," The Proceedings of the First International Symposium of Fire Safety Science, Hemisphere Publishing Corporation, 1986, pp. 1177.

26. Yu, H-Z., Lee, J. L., and Kung, H-K., "Suppression of Rack Storage Fires by Water," The Proceedings of the fourth International Symposium of Fire Safety Science, International Association for Fire Safety Science, pp. 901-912, 1994.

27. Ingason, H., and De Ris, J., "Flame Heat Transfer in Storage Geometries," Publication in Preparation, 1996.

28. FMRC Update "Advances in Commodity Classification", A progress report from Factory Mutual Research Corporation, Vol. 4, No. 1, 1990.

29. Chicarello, P. J., "Large Drop Sprinkler," Technical Report, FMRC J. I 0G0E7. RR, Factory Mutual Research Corporation, Norwood, MA, February 1982.

30. Kung, H. C., Spaulding, R. D. and Hill, E. E., "Sprinkler Performance in Residential Fire Tests," Technical Report FMRC Serial No. 22574, Factory Mutual Research Corporation, Norwood, MA July 1980.

31. Kung, H. C., Spaulding, R. D., Hill, E. E., and Symonds, A. P., "Field Evaluation of Residential Prototype Sprinklers, Los Angeles Fire Test Program," Technical Report, FMRC J.I. 0E0R3.RA, February, 1982.

32. Bill, R. G., et al, "Predicting the Suppression Capability of Quick Response Sprinklers in a Light Hazard Scenario - Part I: Fire Growth and Required Delivered Density (RDD) Measurements," Journal of Fire Protection Engineering, Vol. 3, No. 3, September 1991.

33. Bill, R. G., et al, "Predicting the Suppression Capability of Quick Response Sprinklers in a Light Hazard Scenario - Part II: Actual Delivered Density (ADD) Measurements and Full-Scale Fire Tests," Journal of Fire Protection Engineering, Vol. 3, No. 3, September 1991.

34. Yao, C., "Early Suppression Fast Response Sprinkler Systems" Chemical Engineering Progress, September 1988, pp.38-43. 